\title{
As representações religiosas no cinema de Geraldo Sarno
}

\author{
Gilberto Alexandre Sobrinho \& Felipe Corrêa Bomfim*
}

Resumo: Este texto se ocupa do conjunto de documentários sobre a representação da temática da religiosidade, em diferentes religiões e abordagens, dirigidos por Geraldo Sarno, nas décadas de 1970 e 1980. A realização desses documentários insere-se na passagem sutil e gradual para um novo ciclo na filmografia do diretor, evidenciado por meio do processo de revisão do próprio cineasta sobre sua maneira de documentar. Palavras-chave: Geraldo Sarno; cocumentário brasileiro; cinema e religião.

Resumen: Este texto se ocupa del conjunto de documentales sobre la representación de la temática de la religiosidad en diferentes religiones y abordajes, serie esa dirigida por Geraldo Sarno en las décadas de 1970 y 1980. La realización de estos documentales forma parte de la transición sutil y gradual hacia un nuevo ciclo en la filmografía del director, evidenciado mediante el proceso de revisión del propio cineasta sobre su manera de documentar.

Palabras clave: Geraldo Sarno; documental brasileño; cine y religión.

Abstract: This text deals with the documentaries directed by Geraldo Sarno on the theme of religiosity, in different religions and approaches, in the decades of the 1970s and 1980s. These films reveal a subtle and gradual passage to a new filmmaking cycle, evidenced by Sarno's reviewing of his own way of documenting.

Keywords: Geraldo Sarno; brazilian documentary; religion and film.

Résumé: Ce texte traite de l'ensemble des documentaires sur le sujet de la religiosité dans les différentes religions et approches, réalisés par Geraldo Sarno dans les années 1970 et 1980 . La réalisation de ces documentaires fait partie de la transition subtile et progressive vers un nouveau cycle, comme en témoigne le cinéaste lui-même dans le processus d'examen sur sa façon de documenter.

Mots-clés: Geraldo Sarno; documentaire brésilien; cinéma et religion.

* Gilberto Alexandre Sobrinho: Universidade Estadual de Campinas - UNICAMP, Instituto de Artes, Departamento de Multimeios, Mídia e Comunicação. 13083-854. Campinas (SP), Brasil. E-mail: gilsobrinho@iar.unicamp.br

Felipe Corrêa Bomfim: Doutorando, Bolsista CAPES. Universidade Estadual de Campinas - UNICAMP, Instituto de Artes, Programa de Pós-Graduação em Multimeios. 13083-854. Campinas (SP), Brasil. E-mail: felipecorrea.bomfim@gmail.com

Submissão do artigo: 02 de janeiro de 2017. Notificação de aceitação: 30 de janeiro de 2017.

Doc On-line, n. 21, março de 2017, www.doc.ubi.pt, pp. 51-71. 
Há uma premissa que acompanha a realização fílmica do cineasta brasileiro Geraldo Sarno, sintetizada no seguinte período, repetido em contextos diferentes: "Na verdade o que o documentário realmente documenta com veracidade é a minha maneira de documentar". ${ }^{1}$ Com isso, o diretor se abre para o campo das operações reflexivas que marcam o cinema moderno e autoral, onde ele se situa e se identifica. Assim, assistir aos seus documentários é também testemunhar a forma pela qual os mesmos revelam a construção de seu olhar.

Nesse texto, interessa-nos particularmente refletir como esse processo reflexivo de construção documentária voltou-se especificamente para a temática da religião, com foco no catolicismo e no candomblé. O objetivo é analisar justamente as particularidades enunciativas de seus documentários, que buscam se constituir a partir dessa partilha com o espectador, onde se edifica um projeto reflexivo a partir do documentário, e inclui um programa de afetos atualizados na imagem, em que pesa as relações com religiões, de forma dominante. A partir do estudo dos filmes com esses temas específicos, notamos a presença de modos distintos de lidar com os expedientes do documentário, num processo que conjuga forma e afeto de maneira singular, ou seja, é a experiência com essas religiões que disparam modos particulares de documentar.

Diversos textos discutiram as reverberações do filme Viramundo (1965), documentário que situa Geraldo Sarno na linha de frente do Cinema Novo. Entre os intérpretes, destacou-se Jean-Claude Bernardet ${ }^{2}$, por meio de sua leitura do filme, a partir do que denominou como um "modelo sociológico" perseguido nas imagens e sons. Segundo suas reflexões, tal modelo obteve seu ápice em meados da década de 1960, na visão de que as artes, além de expressar as problemáticas sociais, deveriam ainda contribuir para a formação da sociedade, com destaque para o enunciador fílmico que assumia o controle total da explicação dos problemas apresentados. Os desdobramentos dessas ideias apontam também para outros caminhos, como aqueles desenvolvidos por José Carlos Avellar (1986: 24), que reforçam o caráter plástico dos planos de Viramundo. Observamos esses investimentos na sequência dos operários ou ainda nas sequências que selam o filme, a partir do tema da trilha musical, que busca estabelecer uma analogia à condição social do migrante e seu recomeçar constante. O documentário é exemplo de uma prática em que o tecido formal se ajusta ao ponto de vista do narrador/locutor, a voz do saber. Portanto, sua or-

1. A primeira vez que essa frase surgiu foi no texto Quatro notas e um depoimento sobre o documentário publicado em Filme Cultura número 44, de abril/agosto de 1984.

2. A maior repercussão no âmbito da crítica e da produção acadêmica, se deu, portanto, a partir de meados de 1980 , com a publicação do texto $O$ modelo sociológico ou a voz do dono (Viramundo), em 1985. In: Cineastas e imagens do povo. 
ganização formal, sobretudo em relação à montagem visual e sonora, obedece a esse princípio.

Ainda no contexto de realização entre sua produtora, a Saruê Filmes e Thomaz Farkas, que desencadeou os filmes conhecidos como a Caravana Farkas é possível estabelecer um breve percurso que compreende as pesquisas sobre os processos enunciativos de Geraldo Sarno, algo que inicia em 1964/65 com Viramundo e finaliza em 1970, com Viva Cariri! (Geraldo Sarno, 1969/1970). O trabalho de Clara Leonel Ramos (2007) é uma baliza nesta direção. Em sua análise sobre Viva Cariri! ela descreve o filme como um "documentário de transição", em que se verifica a diluição de um modelo mais rígido de enunciação, enveredando para uma direção "antinaturalista" da montagem, ao se referir aos planos finais do documentário. A presença de tais elementos, entre outros, evidencia o conceito que se desenvolve para a configuração do documentário. Assim, em Viva Cariri!, as dissonâncias em sua estrutura destacam o processo de reflexão e de revisão do cineasta sobre a sua maneira de documentar. A partir de então, o diretor se alça a outros voos, durante a década de 1970, com continuidade nos anos 1980.

A ênfase sobre a maneira de documentar do diretor é delineada no artigo de Sobrinho (2013: 99), ao retomar o texto de Sarno intitulado Quatro notas e um depoimento sobre documentário, ${ }^{3}$ que discute a sua visão sobre algumas pautas dos debates sobre o formato documentário no contexto brasileiro. Dentre as quatro notas elencadas pelo cineasta, ${ }^{4}$ duas são destacadas, a saber: a terceira e a quarta notas. A respeito da terceira nota, Sobrinho salienta a reflexão do documentarista que evidencia os limites nos processos de realização de um filme, abarcados pelos domínios dos meios de realização, de questões técnicas e de produção.

A quarta e última nota reverbera as relações entre o campo das ciências sociais e o documentário. Nessa nota, Sarno afirmou que o moderno documentário brasileiro debruçou-se, inicialmente, nas ciências sociais para elaborar sua poética, no entanto, descartou-a assim que alargou seus espaços através de uma busca por uma poética própria. A liberação desse esteio inicial aponta para experimentações no uso da linguagem e da poética, e também modos mais livres de observação e de escuta, onde se assentam os alicerces dos modos do documentário e a sua permanência.

3. Op.cit.

4. A primeira nota inicia o texto citando Arnol Conceição, segundo ele, o primeiro cineasta documentarista negro da Bahia, em seguida, lança a questão “(...) será que podemos considerar este fato como um marco real de descolonização?"; já a segunda nota apresenta o questionamento sobre certa "inocuidade" da repetição de planos, com a finalidade de garantir o prolongamento da fruição do espectador sobre o acontecimento registrado. 
Acreditamos que os procedimentos ${ }^{5}$ adotados em geral pelo documentário na virada entre as décadas de 1960 e 1970 repercutam de maneira similar aos movimentos empreendidos a partir de então nos filmes de Sarno das duas décadas seguintes. Sendo assim, alinhados ao pensamento de Sobrinho (2013: 99), é possível observar que "de Viramundo a Viva Cariri completa-se um ciclo na poética de Geraldo Sarno". Viva Cariri! apresentou uma maneira diversa de documentar as formas de trabalho e de religião em relação aos documentários precedentes. Esse procedimento abre caminho para a presença de indicativos de mudança nos modos de documentar do cineasta que, ao observarmos em filigrana sua filmografia, delineia a pertinência em sublinhar a existência de outro ciclo para o diretor. Esse novo momento em sua filmografia, particular aos documentários realizados entre as décadas de 1970 e 1980, é marcado pelo processo de revisão do cineasta sobre seus modos de documentar os eventos registrados, em que podemos antecipar as relações de alteridade que se desenvolvem em outras chaves, estabelecendo, assim, uma unidade para esse momento.

Já no primeiro período de sua filmografia apresentam-se fortes imagens marcadas por componentes religiosos, embora não constituam o ponto central dos documentários, seus lugares nos filmes chamam a atenção, justamente por revelarem aspectos inerentes ao ponto de vista e à abordagem constituintes de uma primeira fase. Embora enunciadas por vieses distintos, prevalece a exterioridade do ponto de vista, de um lado, que olha o pentecostalismo católico e evangélico e a umbanda como refúgio e alienação em Viramundo, e, de outro, o catolicismo popular firmado na crença em Padre Cícero como remanescente do messianismo, em Viva Cariri!. São dois aspectos interessantes dessa fase e que testemunham uma forma de olhar, em primeiro lugar, assimétrico em relação ao objeto filmado, ou que se chamou de "a voz do dono", sendo destacada a forte influência das ciências sociais, num jogo livre com a linguagem do audiovisual.

Num segundo momento de sua filmografia, figurado pela atualização de novas abordagens, como cernes sobre uma revisão de sua maneira de documentar, a religião aparece de forma intensa e dominante em alguns filmes. Primeiramente, seu interesse volta-se para o candomblé, por meio da realização de Espaço sagrado (1975) e Iaô (1976). Em seguida, Sarno volta-se para a vertente católica da Teologia da Libertação, nos documentários: A terra queima (1984) e Deus é um fogo (1987).

5. Referimo-nos as pesquisas evidenciadas por José Carlos Avellar (2003: 198), em que havia uma busca no documentário brasileiro de modo geral em dialogar com outras artes, como a poesia, e o âmbito ficcional do cinema, para alargar modelos mais rígidos de enunciação, sendo tal investimento perceptível, segundo o autor, em Viva Cariri!. 


\section{As narrativas de resistência e suas estratégias de registro}

Em 1975, Geraldo Sarno lançou Espaço Sagrado, que descortinou ao nível da exploração do espaço, parte do universo religioso afro-brasileiro, no âmbito do documentário brasileiro. Posteriormente, o diretor investiu num documentário de fôlego sobre a religião do candomblé, intitulado Iaô. A iniciação num terreiro Gege Nagô (1976). Ambos documentários faziam parte de um projeto formulado na década anterior (Sarno, 2006: 209), intitulado A cidade sagrada. A intenção do cineasta era elaborar uma série sobre as religiões afro-brasileiras, tendo como foco central o transe. As obras foram produzidas pela Saruê Filmes ${ }^{6}$, produtora do cineasta que, a partir destes filmes, voltouse para questões ligadas à identidade negra, tal como Ilê Aiyê/Angola $(1986)^{7}$, que celebra o aniversário de dez anos do grupo Ilê Aiyê de Salvador.

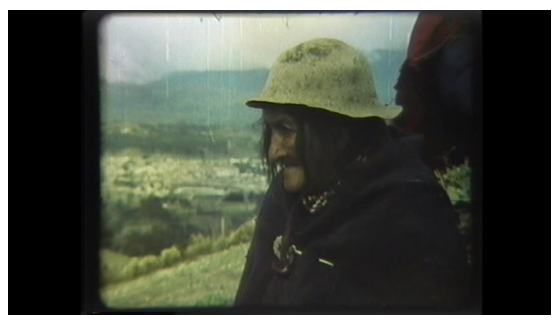

Deus é um fogo

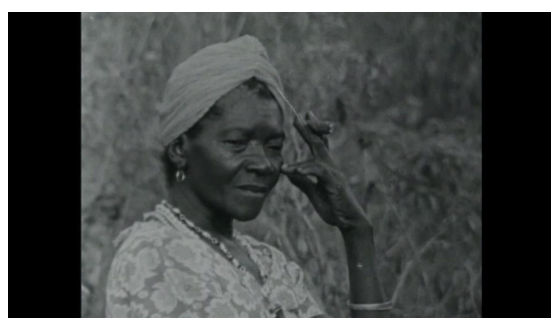

Iaô

6. O filme Iaô divide a produção com a produtora Mariana Filmes e Moisés Kendler, que realizou documentários sobre temáticas da cultura negra nas obras A baiana (1974) e Igreja de pretos e pardos (1976). No caso do curta-metragem Espaço sagrado (1975) foi um trabalho de coprodução do Ministério de Educação e Cultura.

7. Direção e roteiro de Orlando Senna. As pesquisas de Sarno sobre a cultura negra na Bahia não se limitaram ao campo da música, abarcando também as artes plásticas com seu resultado posterior no DVD A imagem cinematográfica e o artista plástico Hélio de Oliveira (2006), em que Sarno investigou artistas plásticos afro-brasileiros como Juarez Paraíso e Hélio de Oliveira. 


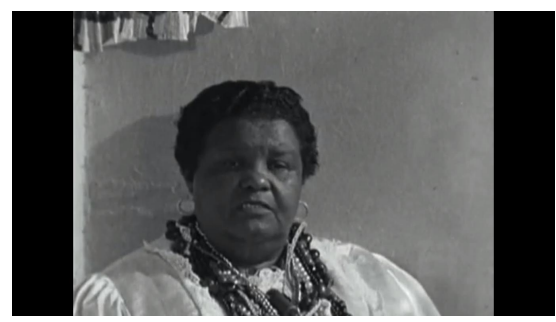

Viramundo

O curta-metragem Espaço Sagrado elabora um olhar exploratório sobre o espaço geográfico do terreiro de candomblé Ilê Axé Ita Ylê, de Mãe Filhinha, localizado em Cachoeira, no Recôncavo Baiano, ao qual o cineasta se aproximou, a partir das leituras do livro do sociólogo Roger Bastide, $O$ candomblé na Bahia, particularmente o capítulo $O$ espaço sagrado e tempos sagrados. As primeiras imagens do filme capturam imagens de casas simples cercadas de áreas verdes e a narração anuncia os propósitos do filme. Aqui a fala enfatiza sobre $o$ aspecto introdutório do filme, a vivência recente do autor do filme em relação ao tema, numa demonstração nítida de mudança na abordagem que visa compartilhar uma aprendizagem. As imagens subsequentes, ainda acompanhadas pela voz over, descrevem sobre os elementos que organizam o terreiro, deixando claro tratar-se de duas tradições que se entrecruzam, por um lado o legado iorubano, candomblecista que cultua os orixás, de outro, o culto dos caboclos que remetem ao bantos, africanos que primeiro chegaram ao Brasil. A câmera vai além do espaço do terreiro para acompanhar Mãe Filhinha de Iemanjá adentrando a natureza e percorrendo as margens de um rio, numa demonstração da amplitude dos espaços sagrados. Repentinamente, a voz over desaparece e o espectador é convidado a deixar-se conduzir pelos atabaques, cantos e transe.

O filme subsequente é o documentário de longa-metragem Iâ. Nesse caso, o foco se desloca unicamente da questão do espaço, para a observação e participação nas atividades dos rituais de iniciação de três jovens mulheres no candomblé, as chamadas Iaôs, no mesmo terreiro. Para a realização do filme, o diretor tomou como referência para suas pesquisas o livro de Juana Elbein dos Santos ${ }^{8}$, intitulada Os nagô e a morte: pàdè, asèsè e o culto ègun na Bahia. Fruto de uma tese de doutorado, foi "obra fundamental da legitimação de uma

8. O trecho específico, utilizado na narração, se refere ao mito de Oxalá. A antropóloga Juana Elbein dos Santos realizou documentários dentro da SECNEB com o objetivo de promover uma perspectiva ligada as propostas desenvolvidas na tese de doutorado como no filme Yia-mi-agbá. Mito e metamorfoses das mães nagô (1981). 
perspectiva afrocêntrica e nagôcentrica, e que se tornaria uma das matrizes do programa do SECNEB" 9 (Santiago Junior, 2009: 98).

Ia ô traz no subtítulo do filme a proposta de tratar do processo iniciático no candomblé, com foco em três iaôs. ${ }^{10}$ Segundo Santiago Junior (2009: 97), não existiam ainda, dentro do contexto cinematográfico do período, documentários que tocassem com profundidade em tais aspectos, dentro de um terreiro nagô baiano ${ }^{11}$. Esta proposta, inovadora na temática, traz a possibilidade, segundo o autor, de elaborar um "novo olhar" sobre algo jamais filmado (Santiago Junior, 2009: 97).

Em entrevista, Sarno (Cesar e Monte-Mor, 1984: 22) declarou que investiga o fenômeno religioso como maneira de compreender a profundidade em suas expressões, ânsias e sentimentos que vem à tona na afirmação de uma religiosidade e que, em outras situações, poderiam encontrar-se estagnados. A identificação com a temática se articula por meio de outra chave de leitura, ao notarmos as declarações do cineasta que afirma que a feitura do documentário "não me faz obrigatoriamente um religioso", mas por outro "me faz [...] porque permite que eu desenvolva em mim mesmo uma sensibilidade religiosa, embora não obrigatoriamente confessional".

Dentro dessa aproximação com a religiosidade, podemos perceber nas declarações do cineasta dois filões: no primeiro, ele acaba por observar na expressão religiosa aspectos ligados a questões sociais, expondo uma possível imbricação entre os dois fenômenos. No segundo, o diretor envereda em uma busca na compreensão de seu próprio trabalho como documentarista.

Como ponto de partida para esses dois filões apontados, enfocamos na segunda direção. De saída, destacamos as negociações empreendidas entre cineasta/equipe e integrantes do terreiro. A autorização para registrá-lo veio por meio de um encontro de Mãe Filhinha e outros pais e mães de santo do terreiro com a equipe restrita em locação, em que a ialorixá informou que "a câmera não tem nem bom nem mau olhado", informando assim a decisão de autorizar as filmagens pela equipe (Avellar, 2003: 193).

9. Em 1974, formou-se em Salvador um importante núcleo a partir de figuras que gravitavam em torno do universo da cultura afro-brasileira, como Mestre Didi, Juana dos Santos e Marco Aurélio Luz, para a fundação da Sociedade de Estudos da Cultura Negra do Brasil (SECNEB). O SECNEB surgiu com o intuito de desenvolver um entendimento mais vasto "da 'civilização negro-africana' na sociedade brasileira" e, para atingir tais fins, contou com "inúmeros membros da comunidade negra do Brasil aos esforços de cientistas sociais, intelectuais e artistas" (Santiago Junior, 2009: 98).

10. Ia ô é o título dado ao membro do terreiro, já iniciado em primeiro grau, que cumpriu todas as obrigações necessárias dentro do longo processo de iniciação do candomblé.

11. Essas questões relacionadas à mãe-de-santo Narcisa Cândida Conceição foram aprofundadas no texto Boa morte. Das memórias de Filhinha às litografias de Maragogipe, de Sebastião Heber Vieira Costa. 
O consentimento para as filmagens aconteceu ainda na fase de pré-produção, sendo assim, ela não aparece no documentário. Houve ainda uma segunda autorização, sendo esta presente na narrativa. Trata-se da sequência em que vemos um membro do terreiro realizando a limpeza de corpo do cineasta Geraldo Sarno, evidenciando a sua presença física no plano. A sequência sucede a outras relacionadas aos ritos preparatórios, como o banho na fonte sagrada, e preliminares como a despedida dos caboclos do terreiro, durante o nascimento das novas iâss, conforme indicado pela voz over. A presença do próprio diretor, filmado em algumas práticas rituais, como na sequência da limpeza de corpo ou ainda no plano em que o cineasta faz uma oferenda ao orixá Oxalá, aponta para uma ampliação do repertório de materiais que o cineasta se dispõe para a articulação do documentário. Na sequência da limpeza de corpo vemos ainda a presença de dispositivos cinematográficos como câmera, equipamento sonoro, além de alguns dos integrantes da equipe, tais estratégias ainda não haviam sido utilizadas pelo diretor em seus documentários precedentes.

A condição pressuposta como consentimento para as filmagens dos ritos finais de iniciação, gerada pelas circunstâncias de produção do filme, ocasionou a decisão do cineasta de realizar a sequência do ebó para Oxalá e é interessante notar os desdobramentos cinemáticos desse acontecimento. Durante o zoom out da câmera - de um plano detalhe do ebó no Rio Paraguaçu para um plano geral do objeto flutuando no rio - o cineasta se depara com elementos presentes no plano da imagem que, segundo ele, remetem diretamente ao mito de Oxalá. $^{12}$

As aproximações são bastante produtivas quando pensadas a partir das marcas deixadas durante o cumprimento das atividades religiosas, de modo particular na sequência da 'limpeza de corpo'. Essa sequência apresenta a decisão do diretor em filmar-se no banho de ervas e o processo é registrado por duas câmeras simultaneamente, uma em película colorida e a segunda em monocromático. $\mathrm{O}$ ato de registrar esse procedimento com duas câmeras e o próprio posicionamento da câmera monocromática, bastante próxima do cineasta, sublinha a circunstância do registro por meio do veio performático.

Para além das discussões ligadas às estratégias de registros utilizadas, cabe salientarmos a particular atualização do candomblé no filme como forma de resistência cultural. Essa linha de força se ramifica em outras direções menores, em particular às dinâmicas relacionadas à individualidade das iaôs e o fato de suprimir o nome do terreiro documentado.

12. Sarno(2013a) declara que "a imagem do filme reproduz a cuia do céu, Oxalá, o mar, a terra e as duas mães de santo [...] tudo isso está na imagem”. A propósito do mito de Oxalá, o sociólogo Roger Bastide (2009: 85) elucidou que mito ioruba do casal ancestral - Obatalá (outro nome de Oxalá no Brasil), o céu, e Odudua, a terra - em união representa-se por duas meias cabaças fechadas, uma sobre a outra. 
Em um primeiro momento, a percepção de uma perspectiva particularizada em documentar um único terreiro de candomblé apresentaria certas lacunas na contextualização do ritual, como questões implícitas em elidir a localização geográfica do próprio terreiro ou ainda na exposição das abiãs sem referências às suas vidas cotidianas, fora do espaço circunscrito do terreiro. Apesar de não mencionar os nomes das personagens, o documentário dispõe de um procedimento bastante rico no desenvolvimento de uma identidade das iaôs que, não obstante sua sutileza percorre todo o processo iniciático documentado no filme. De fato, os títulos dados às abiãs nas primeiras sequências correspondem a ordem de constituição do "barco", sendo que, como destacou o sociólogo Luis Nicolau Parés (2011: 261) "os títulos dofona, dofonitinha, fomo, etc. indicam a ordem de entrada no grupo de iniciados e a sua ordem de preparação ritual".

As dinâmicas relacionadas à individualidade das iaôs no filme são sensíveis às próprias etapas do ritual iniciático. Esse processo é perceptível a partir da diluição de suas personalidades, ao final das sequências "Catulagem" e "Raspagem", comentadas pela voz over do filme. A narração elucida minuciosamente este procedimento ao longo do documentário, de modo que na sequência do "Sundidé" a voz over indica, como nascimento da futura individualidade, as trocas energéticas "de axé entre o aiê, este mundo, e o orum" 13 como responsáveis para a formação das novas iaôs.

Na sequência "Terceiro Sarapocã - o nome" temos o ponto de inflexão da individualidade das iâ̂s no filme. Os nomes que tinham sido mantidos em segredo desde o momento final da sequência da "Raspagem" são finalmente anunciados no barracão de festas. Esta sequência é intervalada por três outras menores que dedicam sua duração, de cerca de um minuto, para cada uma das três iaôs nesta etapa final do ritual. Tais sequências possuem cartelas de apresentação, com o nome do respectivo orixá de cada iaô, sucedido do nome que será anunciado no barracão, ordenadas em: "Iemanjá - Ogunté", "Oiá Adê Ilê Uá" e "Obaluiaiê - Corumba".

Além das três breves sequências que recortam a sequência maior do "Terceiro sarapocã - o nome", notamos que ela está ainda intercalada pela última entrevista do documentário. Acreditamos que, diferentemente das duas primeiras entrevistas, a última entrevista apresenta um resultado bastante produtivo na 'voz' do documentário, devido à sua disposição na narrativa do filme.

O terreiro de Mãe Filhinha não é de fato mencionado ao longo do filme, mas ao estudarmos as minúcias presentes na última entrevista, realizada com a ialorixá e seu companheiro, observamos que o fato de nomeá-los prejudicaria

13. A voz over do documentário Iaô refere-se ao orum como "espaço ilimitado onde habitam os orixás". 
todo um trabalho de montagem no qual o filme se constrói e que buscaremos elucidar nas próximas linhas.

Durante o longo depoimento do casal, ${ }^{14} \mathrm{o}$ cineasta incita suas memórias a um retorno às décadas anteriores, elencando diversas barbáries realizadas pelas "milícias" que depredaram vários terreiros nas cidades da região do Recôncavo Baiano. Apesar de implícito nas falas do depoimento, este é o primeiro momento em que o terreiro é localizado geograficamente por meio de seus arredores.

O depoimento do casal caminha em outra direção ao serem questionados sobre a a situação vigente em que se encontram. As tribulações e repressões transformam-se em esperança e luta por direitos empreendidas pelas comunidades da região, a partir de colaborações entre o continente africano e Brasil, na voz de concidadãos lá presentes, como demonstra a entrevista. Os depoimentos desta sequência ainda informam sobre o reconhecimento do candomblé pelo alto escalão da política, através do breve comentário do cineasta sobre o decreto de um governador, que reconhece a importância da religião do candomblé, além da própria milícia, na conversão de um comandante em filhode-santo. Neste sentido, a decisão em não apresentar o nome do terreiro se constitui em uma maneira de fortalecer a sua possibilidade de generalização, provavelmente necessária para colocar os terreiros da região no mesmo grau de importância, em detrimento das especificidades do terreiro filmado, e pensar a religião do candomblé como forma de resistência cultural e social.

Essa intencionalidade de generalização é justamente o norte tomado por meio da disposição da terceira entrevista na narrativa do filme. O conteúdo da entrevista está afinado às relações e experiências vividas pela comunidade e à postura de não tratá-la como caso isolado, apartando-a de experiências similares ocorridas em outros terreiros da região.

Retomando a articulação das sequências finais, evidenciamos anteriormente a localização da última entrevista e das três breves sequências com o nome das iaôs no intervalo da sequência do "Terceiro sarapocã - o nome". Neste último Sarapocã são informados à comunidade presente no barracão de festas os nomes das novas iaôs, estabelecendo-se, portanto, a afirmação de uma identidade estreitamente vinculada ao candomblé.

A disposição intercalada dos depoimentos do casal na sequência do "Terceiro Sarapocã - o nome" nos permite observar dois movimentos. No primeiro temos uma leitura do aspecto social a partir das potencialidades da religião do candomblé, devido à sua inscrição no intervalo da sequência do Sarapocã. No segundo movimento, observamos a leitura de um reconhecimento dado em

14. A sequência da entrevista ao casal dura 4 minutos e meio. 
duas dimensões: uma micro, em que temos as identidades das iaôs reconhecidas perante a comunidade de terreiros da região; e uma macro, pertencente a própria dinâmica do filme, que caminha para um respeito e admiração da comunidade documentada perante a sociedade.

\section{A passagem da igreja 'teológica' à 'popular': religião, encontro, afeto e política}

Na década de 1980, o cineasta Geraldo Sarno voltou-se para o fenômeno religioso da Teologia da Libertação, tratando-se de uma nova vertente do catolicismo que adquiriu bastante força e penetração a partir dos anos $1970{ }^{15} \mathrm{e}$ cuja principal vocação era focar nos pobres e nutrir debates religiosos em diálogo com o conhecimento das humanidades e ciências sociais. Os documentários que figuram o seu interesse por esse universo são o média-metragem $A$ terra queima (1984), em trechos específicos, e o longa-metragem Deus é um fogo (1987).

O documentário A terra queima nasceu de um conjunto de dez filmes patrocinados pela ONU (Organização das Nações Unidas). ${ }^{16}$ A terra queima trata, em grande parte de sua narrativa, da estiagem ocorrida durante o início da década de 1980 "quando se completavam quatro anos consecutivos de seca no Nordeste" (Labaki, 2001: 101). A questão fundiária se desdobra em diversas facetas, dentre elas a questão da demarcação de território indígena dos Kaimbés ${ }^{17}$, no estado da Bahia. A apresentação de Sarno à comunidade indígena foi feita por intermédio de uma carta dos antropólogos Maria Rosário de Carvalho e Edwin Reensik, endereçada à "Maroto, Silvino e demais amigos

15. Em sua tese de doutoramento, Mairon Escorsi Valério, (2012: 14), comenta o surgimento da Teologia da Libertação na década de 1970, a partir da adoção das Comunidades Eclesiais de Base (CEBs). Dentre os diversos estudos que descreveram a Teologia da Libertação, salientamos a progressão do interesse nesta temática presente nas edições da Revista Comunicações do ISER - Instituto de Estudos da Religião -, que apresenta diversas pesquisas sobre este movimento, como o artigo de Frei Betto O que é Teologia da Libertação? (1984), além do texto de Sandra Stoll, publicado na revista no ano anterior, Embu, Eleições 1982: a mobilização política de CEBS e pentecostais - um estudo de caso (1983), que sublinhou a articulação política das CEBS, Comunidades Eclesiais de Base da Igreja Católica.

16. O projeto contou com dez realizadores de países da África, Ásia e América Latina, como o Equador e o Brasil. Os países selecionados pela ONU para a produção dos filmes foram Japão, Canadá, e alguns países do continente Europeu, além de o encargo de distribuição dos filmes no próprio país onde fora realizado, sendo, em seguida, distribuídos nos outros países da ONU (OCIC, 1985, p. 3). A terra queima foi configurado como média-metragem, para ser veiculado no circuito televisivo, haja vista as demandas dos acordos de produção, estipuladas nas reuniões da Agenda For a Small Planet. Sarno desenvolveu um projeto relacionado à questão fundiária no Brasil e sua proposta foi apreciada pela emissora pública finlandesa Yleisradio Oy (Ile Tv) e a televisão pública canadense Societé Radio Canada, sendo esta última responsável por sua produção, juntamente a coprodução da Saruê Filmes.

17. Cabe salientar que nos documentos e fotografias de filmagens encontramos escritos à mão do diretor que mencionam o território indígena dos Pankararés. 
Kaimbé" ${ }^{18}$. Outro desdobramento da narrativa do filme discute as consequências da seca como "a falta de água, a falta de comida, a falta de emprego [...], o trabalho comunitário, a mortalidade infantil" (Pierre, 2001: 101), e o desdobramento de suas soluções provisórias, como abastecimento de água precário por meio de caminhões pipa ou ainda o "Bolsão da Seca", ${ }^{19}$ esmiuçado em sequências específicas do filme.

A voz over recorre às estatísticas para afirmar o índice exorbitante de mortalidade infantil na região do Nordeste, enquanto a câmera passeia em um hospital, filmando uma série de bebês em condições graves de saúde. No trecho seguinte, vemos um velório de um recém-nascido ao som da cantiga infantil "nana neném", intercalada ao poema de João Cabral de Melo Neto, "Duas das festas da morte". ${ }^{20}$ A terra queima investe sua narrativa nas diversas atitudes tomadas pelas diferentes comunidades retratadas no filme, como a influência perceptível do movimento da teologia da libertação em estados como Ceará, Paraíba, Pernambuco ou Bahia.

Tais atitudes são evidenciadas pelo diretor como formas de reação bastante contundentes e inesperadas, em particular, ao visitar as comunidades de base do sertão da Bahia, sendo este impulso e energia encontrados ali que despertou o olhar do cineasta (Sarno, 2006: 209) para fazer um documentário sobre a teologia na América Latina. O projeto do longa-metragem Deus é um fogo foi apresentado pelo cineasta à Televisión Española (TVE) com o intuito de coprodução, sendo tal procedimento viabilizado somente após grande parte da produção do filme ter sido encaminhada pela própria produtora do cineasta, a Saruê Filmes. ${ }^{21}$ O cineasta encontrou apoio no Instituto Cubano de Arte e Indústria Cinematográficos (ICAIC) e outras instituições ${ }^{22}$ para a realização de seu documentário, filmado em sete países da América Latina, dentre os quais: México, Cuba, Peru, Equador, El Salvador e Nicarágua, além do Brasil.

Em Deus é um fogo, o diretor entrevistou importantes teólogos e pensadores da Teologia da Libertação, além de ter realizado fortes registros de cultos católicos nos diversos países do continente envolvido. É preciso considerar $1 \mathrm{p}$.

18. Reesik e Carvalho. [Carta] 3 de fevereiro de 1984, Salvador [para] Comunidade Kaimbé.

19. A voz over do documentário referiu-se ao "Bolsão da Seca" como Plano Governamental de Emergência, sendo a sua finalidade a "de fixar o lavrador no campo e dar-lhe algum meio de subsistência".

20. O poema Duas das festas da morte está presente no livro A educação pela pedra e outros poemas. Rio de Janeiro: Objetiva, 2008. p. 203.

21. Sarno (2014b) declarou que a coprodução realizou-se de fato somente após a produção do filme, durante a apresentação do filme no 6o Festival Internacional del Nuevo Cine Latinoamericano, em Havana, Cuba.

22. Além da produtora e distribuidora EMBRAFILME, o esteio de outras instituições foi obtido, na maior parte dos casos, durante o período de estadia nas próprias locações do documentário. 
que o otimismo com o movimento religioso, em escala internacional, havia alcançado um forte retrocesso, devido à resistência e oposição do Vaticano, na figura do Papa João Paulo II, em conluio com a ascensão da ideologia políticoeconômica dos princípios neoliberais e sua grande influência no capitalismo global. Mesmo assim, havia uma força nessa igreja popular e transformadora. Em relação à maneira como o filme lida com esses elementos, vamos destacar sequencias em que Sarno reitera essas características, utilizando-se de expedientes cinemáticos para a construção de sequencias fortemente simbólicas, indo, portanto, além dos recursos que as entrevistas oferecem.

Em diversos momentos de Deus é um fogo sente-se o uso de imagens que indicam uma sobreposição de temporalidades, perceptível em trechos como a primeira sequência do filme, onde vemos majestosas ruínas acompanhadas de imagens de um músico local, tocando uma espécie de harpa. A sequência seguinte, com as imagens de orações indígenas realizadas no espaço interno de uma igreja, parece estar em consonância com esse procedimento que evidencia imagens descontínuas e fragmentadas em diversos trechos do documentário. ${ }^{23}$ Esse tipo de imagens etéreas, que tendem a uma abstração conceitual, configuram contrastes e um saber intelectual dedicado à montagem que podem remeter à herança einsteiniana do diretor.

Entre os elementos relacionados ao universo religioso, podemos sublinhar um tempo maior dedicado às cerimônias religiosas. Grande parte dos rituais figurados em Deus é um fogo não são explicitados ou descritos. Os possíveis motivos para esta decisão poderiam estar na tentativa de assumir uma perspectiva interior à visão religiosa, por meio do ato de elidir explanações sobre os ritos expostos, considerando tais rituais subentendidos pelo espectador. ${ }^{24}$

Deus é um fogo apresenta e atualiza o fenômeno da Teologia da Libertação como contraponto a uma Igreja institucionalizada, hierarquizada e colonialista. O respeito pelas comunidades ancestrais evidenciam um teor pós-colonialista nas falas, por exemplo, de um bispo mexicano, considerando a herança dos povos indígenas. Notamos um procedimento similar nas falas do Monsenhor Jaime Ortega, em Cuba, que menciona o sincretismo religioso entre o catoli-

23. Além dos trechos já mencionados, podemos salientar uma característica similar nas imagens do segmento dedicado à festa da colheita, com suas diversas danças, máscaras e fantasias, ou ainda em alguns momentos marcados por planos gerais de paisagens, do segmento filmado em Riobamba, no Equador.

24. No estudo sobre os filmes de temáticas religiosas realizados na década de 1970, Bernardet (1994; 1996), sublinhou a proposta de Nelson Pereira dos Santos no longa-metragem $O$ amuleto de Ogum (1974) como uma tentativa de inserção dos elementos religiosos na própria narrativa, a partir da postura de elidir explanações sobre os atos religiosos ali expostos. Tal procedimento de reelaboração da narrativa a partir de tais elementos realiza-se de fato, segundo o autor, somente a partir do documentário de Juana Elbein dos Santos Yia-mi-agbá. Mito e metamorfoses das mães nagô (1981). 
cismo e os cultos iorubás com o orixá Obaluaê, por detrás da imagem venerada no santuário de São Lázaro.

Embora haja a forte presença da voz de autoridades eclesiásticas distribuídas ao longo das geografias documentadas, Deus é um fogo apresenta uma pluralidade de vozes que são consideradas, configurando sua atualização como igreja libertadora que avança pela América Latina, valorizando esses sujeitos e suas comunidades, que passam também a ter voz.

No bloco de sequências filmadas no Brasil, podemos observar uma construção bastante elaborada, sobretudo em relação ao tratamento que recebe a missa, por exemplo. Outro aspecto destacado diz respeito à filmagem de rituais que são ressignificados ${ }^{25}$ dentro da narrativa. Assim como a cruz dissocia-se diretamente da figura de um único mártir, Jesus Cristo, para figurar os diversos mártires sucumbidos nas lutas sociais e políticas mencionadas ao longo do filme. Neste impulso, caminham outras referências presentes em outros segmentos, como as declarações de Frei Lorscheider sobre o sangue de mártires derramados, intercaladas por dois breves momentos, em que revemos, por exemplo, duas viúvas desses referidos mártires assassinatos em lutas sociais, ambas com uma cruz de madeira na mão.

Em meio à pluralidade de rituais presentes na cerimônia da missa, o trecho recortado para a sequência posterior às declarações do Monsenhor Aloísio Lorscheider é justamente o momento da consagração, primeiramente da hóstia e, em seguida, do cálice. Notamos que, diferentemente dos outros trechos, o padre que realiza a consagração não é nomeado a partir das descrições na parte inferior da tela ${ }^{26}$. O trecho registra o ritual de consagração do cálice, que representa a transformação simbólica do vinho em sangue, por meio das frases proferidas pelo sacerdote "este é o cálice do meu sangue, sangue [...] que será derramado por vós e por todos os homens para a remissão dos pecados". Essas frases trazem, em nossa leitura, uma referência às prédicas de Lorscheider ao declarar que o "sangue derramado" dos mártires não foi em vão. Outro indício desta ressignificação do "sangue derramado" está presente no próprio plano do registro da consagração, em que vemos uma faixa ao canto direito do quadro, com a escrita: "porque sangue para ficarmos na terra?".

25. Apesar de o termo "ressignificação", utilizado pelo crítico Jean-Claude Bernardet (2004: 71) referir-se a imagens de arquivo, em sua "transposição de uma imagem de um contexto fílmico para outro, modificando-lhe a significação", optamos por utilizá-la neste contexto, pois acreditamos queexprima a passagem de um símbolo religioso conhecido para a sua nova significação no produto do filme.

26. Apesar dos textos apresentarem, em sua grande parte, os nomes dos personagens de cargo eclesiástico, podemos excetuar as referências dos textos que apresentam o Comandante Tomás Borge, na segunda sequência de Nicarágua e Doña Rosa, na sequência final do filme, em Riobamba, no Equador. 
No início da sequência da "Missa de 1o de Maio" temos um longo registro ${ }^{27}$ da uma cerimônia católica na cidade de Porto Feliz, no interior do estado de São Paulo. O documentário retoma a temática dos mártires ao registrar a missa de 1o de maio, que, como relembra uma depoente no púlpito da igreja: "dedicaram a data de 10 de maio à lembrança dos mártires operários e consagraram-no como dia de luta da classe operária" ${ }^{28}$. Acreditamos que a conclusão desta sequência aponte para duas direções: a primeira confere uma diluição da referência do martírio uno de Cristo para uma pluralidade figurada pelos diversos ativistas mortos em prol das lutas sociais e a segunda, que transpassa o aspecto religioso ali figurado e oferece uma leitura mais ampla dentro da estrutura do filme. Este segundo veio está alinhado às reflexões de Frei Leonardo Boff ao declarar que o filme "soube desocultar o que se esconde por detrás deste fenômeno social e religioso: a fé confrontada com a injustiça se transforma em motor de libertação" (Boff apud Millarch, 1989: 08).

Durante a montagem paralela, em que ouvimos as declarações do Monsenhor Cláudio Hums e vemos os planos da siderúrgica inseridos neste mesmo trecho da sequência da "Missa de 1o de Maio", notamos a ausência total de ruídos diante dos trechos das imagens da siderúrgica. A voz ausente dos trabalhadores não é cedida por meio do sermão de Hums. Acreditamos que ela esteja diretamente vinculada "a dimensão libertadora" desta Igreja transformadora, explicitada pelo sacerdote em suas prédicas no trecho que precede o primeiro plano da siderúrgica. Deste modo, a relação entre as falas sobre a "dimensão libertadora" da Igreja e o primeiro plano do recipiente derrubando o metal líquido, em estado incandescente, nos remete à voz over dos fragmen$\operatorname{tos}^{29}$ de Heráclito de Éfeso, presentes no documentário: "Deus é dia e noite, inverno e verão [...] ele se transforma como o fogo".

Os contrastes entre o sermão de Hums e as imagens da siderúrgica, associados às disparidades na banda sonora, apresentam as transformações da Igreja a partir de uma leitura dialética. A dimensão libertadora, presente nas prédicas de Hums, evidencia a passagem de uma Igreja "teológica" para a Igreja "popular" ${ }^{30}$. Os oprimidos são os responsáveis por esta transformação, figurada na

27. Apesar de algumas imagens da missa de 1o de maio estar intercaladas com imagens feitas em uma siderúrgica, a sua duração completa é de cerca 9 minutos.

28. As declarações da depoente referem-se a data da greve geral ocorrida em 1886, na cidade de Chicago, nos Estados Unidos. A greve, organizada por trabalhadores, reivindicava jornada de 8 horas de trabalho, proteção ao trabalho da mulher e do menor e melhores condições de vida.

29. De modo especial o fragmento 67. Os fragmentos de Heráclito de Éfeso estão presentes no livro de Charles H. Kahn A arte e o pensamento de Heráclito: uma edição dos fragmentos com tradução e comentário.

30. Esta dualidade, catolicismo "teológico" e catolicismo "popular", é expressa nos estudos de Claudia Mesquita (2006: 25) em sua tese de doutoramento, ao referir-se à valorização deste último dentro do campo do documentário, em meados da década de 1970. 
montagem paralela por meio dos operários da siderúrgica. $\mathrm{O}$ ato dos operários moldarem em fôrmas o líquido incandescente reforça a ideia de transformação por meio da fluidez, visto que no fragmento específico mencionado acima, Heráclito de Éfeso se refere ao fogo como "força configuradora do mundo" (Nietzsche, 2008: 64).

Neste impulso, sentimos que o olhar do cineasta voltou-se para a dimensão dada às dinâmicas de transformação em detrimento as datas históricas de tais periodizações, já que não recorre a elas ao longo do documentário. O retorno à 'cosmogonia indígena' ${ }^{31}$ nos trechos finais exemplificam a intenção de extrapolar uma dimensão cíclica na estrutura do filme. Os depoimentos de Monsenhor Leónidas Proaño - intercalados no documentário com as imagens registradas na comunidade de Riobamba, no Equador - presentes na última sequência do filme, sublinham elementos como o respeito dos indígenas com a terra e valor atribuído a ela. Tais reflexões tocaram particularmente o cineasta durante o processo de realização do filme, sendo esse movimento perceptível na narrativa do documentário ao observarmos que o cineasta sela as etapas da Teologia da Libertação com duas sequências sobre a 'cosmogonia indígena', a primeira, no início do filme no México e a última, em Riobamba, no Equador.

As considerações de Proaño sobre a 'cosmogonia indígena' são intercaladas por dois segmentos dedicados as falas da camponesa Doña Rosa e imagens etéreas traduzidas em planos gerais das paisagens próximas ao vulcão Chimborazo, em Riobamba, no Equador. Sentimos que a maneira como esses segmentos são intercalados no trecho final do documentário sublinha a relação da Teologia da Libertação, por meio das declarações de Proaño, que assimila e divulga a 'cosmogonia indígena'.

Este duplo movimento - das transformações religiosas, em suas periodizações no filme, e do próprio ciclo de vida desses mártires - é cingido por uma interpretação do cineasta sobre o retrocesso da Teologia da Libertação. Seu arrefecimento, no período de realização do filme, faz o cineasta enveredar por outros caminhos, deparando-se com a riqueza da 'cosmogonia indígena', que, segundo Proaño, em referência à Teologia da Libertação, "nasce da mesma entranha destas minorias [...] que são os indígenas".

Ao valorizar a essência dos aspectos naturais da 'cosmogonia indígena', o discurso de Proaño conflui na concepção de uma teologia diversa, "que deve ser ainda inventada". Os depoimentos de Proaño evidenciam um rascunho no qual o documentário, a guisa de conclusão, opta em sublinhar. A partir desta

31. A expressão utilizada entre aspas nesse estudo busca atribuir uma referência concisa as duas comunidades figuradas no filme, da região de Riobamba no Equador e do México. Reconhecermos a pluralidade de acepções que esse termo possa acarretar, porém priorizamos essa breve menção de modo a não prejudicar o andamento final da análise do filme. 
sintonia com os pensamentos de Proaño acreditamos que a aproximação do cineasta com a Teologia da Libertação resulte em uma interpretação do movimento religioso que encaminha a leituras consonantes à 'cosmogonia indígena'. Deste modo, a valorização das transformações e da fluidez transforma Deus em fogo ${ }^{32}$ e a Teologia da Libertação em parte deste mesmo. ${ }^{33}$

\section{Considerações Finais}

Diante do estudo crítico dos filmes, deparamo-nos com a flexibilidade do diretor frente às questões de ordem técnica e às limitações impostas pelo processo de produção de seus filmes. De saída, pudemos observar que esses modos de construção se conceberam de maneira particular, na maioria dos casos. Assim, pudemos observar que a singularidade no conjunto da obra de Geraldo Sarno é caracterizada pelo modo como o diretor lida com as imposições de ordem técnica e de produção e reverbera os aspectos de seu pensamento em circulação no momento que realiza os filmes.

Notamos uma grande variação nos investimentos formais traduzidos em momentos de radicalização, evidenciados por um olhar mais subjetivo do diretor e, em outras situações, ofuscados pelas próprias demandas de produção. Portanto, ponderamos que o estilo do cineasta se adequa e dialoga com as diretrizes institucionais dos meios de realização, considerando limitações ou liberdades orçamentárias em cada caso específico de seus filmes. Isso atado à conexão de ideias em construção faz com que a temática religiosa deslize desde abordagens fortemente exteriorizadas, numa primeira fase, até a imersão do diretor nos rituais, num gesto radical de olhar e de escuta que reverbera numa forte alteridade.

Em decorrência dessa lógica observada no andamento de sua obra, delineamos novo ciclo na filmografia do cineasta. A característica mutável de seu estilo nos permitiu entender esse processo de afirmação de uma nova fase vinculada a elementos comuns que conseguimos delinear na sua filmografia do período da década de 1970 e 1980.

Para os fins deste estudo, sintetizamos a seguir alguns elementos que marcam essa mudança. Primeiramente, em Iâ temos a presença física do diretor em duas sequências do filme, além dos dispositivos cinematográficos, como câmeras e equipamentos sonoros e equipe de filmagem. A ampliação do repertório de materiais que o cineasta dispõe para o registro delineia mudanças

32. Titulo do documentário Deus é um fogo.

33. Referimos-nos ao pensamento do filósofo Heráclito de Éfeso, que atribuiu ao fogo a função de "força configuradora do mundo". A filosofia na era trágica dos gregos. Friedrich Wilhelm Nietzsche. Trad. Fernando R. de Moraes Barros. p. 64. 
de abordagem que estabelecem procedimentos de observação e participação e antecipam o veio performático do documentário. Em segundo lugar, o resultado da disposição das sequências do filme que sublinha a atualização do candomblé como forma de resistência cultural e aponta, de maneira sutil, para as dinâmicas relacionadas à individualidade das iaôs e a uma leitura do aspecto social a partir das potencialidades do candomblé, descortinado pela entrevista final com a mãe-de-santo.

Em Deus é um fogo a atualização da religião investe na passagem de uma igreja 'teológica' à 'popular', com ênfase na dimensão transformadora da Teologia de Libertação, figurada em trechos como a montagem paralela entre o sermão de Hums e as imagens da siderúrgica. Nesta direção, caminham o teor pós-colonialista das falas dos bispos entrevistados e as sobreposições de temporalidades nas sequências sobre religiosidade indígena no início e conclusão do filme. O recurso à 'cosmogonia indígena' no filme enfatiza um documentário que lida com expedientes de observação, participação e poético, portanto, multifacetado, com diversas leituras possíveis, salientando a valorização das transformações e da fluidez como aspectos pertinentes à religiosidade.

\section{Referências Bibliográficas}

Avellar, J. C. (2003). Geraldo Sarno. In P. Paranagua, Cine documental en America Latina. (pp. 187-199). Madri: Cátedra.

Avellar, J. C. (1985). O cinema dilacerado. Rio de Janeiro: Alhambra.

Bastide, R. (2009). O candomblé na Bahia. Rito nagô. São Paulo: Companhia das letras.

Bernardet, J-C. (1980). Anos 70. Cinema. São Paulo: Ed. Europa.

Bernardet, J-C. (1996). Cinema e religião. In I. Xavier (org.), O cinema no Século (pp. 187-194), 1 ed. Rio de Janeiro: Imago.

Bernardet, J.-C. (1994). Cinema novo, anos 60 e 70: a questão religiosa. In J. Schwartz \& S. Sosnowski (org.), Brasil: o transito da memória (pp. 101-111). São Paulo: Edusp.

Bernardet, J-C. (2003 [1985]). Cineastas e imagens do povo. São Paulo: Companhia das letras.

Cesar, W. \& Monte-Mor, P. (1984). Entrevista Geraldo Sarno. Revista Comunicações do ISER, 3 (10): 13-26.

Gutierrez, G. (2000 [1971]). Teologia da libertação: perspectivas. São Paulo: Loyola. 
Pierre, S. (1985). Brésil. Les films de la terre. Journal Le Monde, Paris, [03/jan./1985], p. 12-13.

Kahn, C. (2009). A arte e o pensamento de Heráclito: uma edição dos fragmentos com tradução e comentário. São Paulo: Paulus.

Labaki, A. (2001). Retrospectiva Geraldo Sarno. In A. Labaki (org.), VI Festival Internacional de Documentários (pp. 92-102), São Paulo: Festival É tudo verdade.

Leal, H. (2008). Orlando Senna: o homem da montanha. São Paulo: Ed. Imprensa Oficial.

Mesquita, C. (2006). Deus está no particular. Representações da experiência religiosa em dois documentários brasileiros contemporâneos. São Paulo: Tese de Doutorado, Universidade de São Paulo.

Millarch, A. (1989). Uma visão corajosa da teologia da libertação. Jornal Estado do Paraná, janeiro 20, p. 8.

Millarch, A. (1989). É fogo o desperdício de um material sério. Jornal Estado do Paraná, janeiro 24, p. 3.

Nietzsche, F. (2008). A filosofia na era trágica dos gregos. São Paulo: Hedra.

Prandi, R. (1995). As religiões negras do Brasil. Para uma sociologia dos cultos afro-brasileiros. Revista Universidade de São Paulo, (28): 64-83. São Paulo.

Pares, L. (2011). A formação do candomblé: história e ritual da nação jeje na Bahia. Campinas: Editora Unicamp.

Pierre, S. (2001). Retrospectiva Geraldo Sarno. In A. Labaki (org.), VI Festival Internacional de Documentários. Festival É tudo verdade (pp. 101). São Paulo.

Ramos, C. (2007). As múltiplas vozes da Caravana Farkas e a crise do "modelo sociológico”. São Paulo: Dissertação de Mestrado, Universidade de São Paulo.

Santos, J. (2002). Os nagô e a morte: pàdè, asèsè e o culto ègun na Bahia. Rio de Janeiro: Vozes.

Santiago Junior, F. (2009). Imagens do candomblé e da umbanda: etnicidade e religião no cinema brasileiro nos anos 1970. São Paulo: Tese de Doutorado, Universidade Federal Fluminense.

Sarno, G. (2013). Anotações próprias e impróprias. In J. C. Avellar (ed.), A linguagem do cinema (pp. 9-14), 1 ed.. Rio de Janeiro: Instituto Moreira Salles. 
Sarno, G. (2006). Cadernos do Sertão. Salvador: Núcleo de Cinema e Audiovisual.

Sarno, G. $\left(2013^{\mathrm{a}}\right)$. Como nasce o documentário. Curso ministrado na Universidade Estadual do Sudoeste da Bahia (UESB), Vitória da Conquista. Material registrado em formato audiovisual. março 11.

Sarno, G. (2013b). Entrevista concedida ao autor do texto. Belo Horizonte. Registrado em formato áudio. julho 11.

Sarno, G. (2014b). Depoimento concedido ao autor do texto. Material registrado em formato áudio. abril 17.

Sarno, G. (1995). Glauber Rocha e o cinema Latino-Americano. Rio de Janeiro: Centro Interdisciplinar de Estudos Contemporâneos (CIEC) UFRJ.

Sarno, G. (2010). Quatro notas e um depoimento sobre documentário. Filme Cultura, 5 (43-48): 193-196. Rio de Janeiro: Ed. Fac-similar, Centro Técnico Audiovisual (Ctav). Originalmente publicado (1984). Filme Cultura, (44): 61-64. Rio de Janeiro.

Sobrinho, G. (2013). Os documentários de Geraldo Sarno (1964-1971): das catalogações e análises do universo sertanejo aos procedimentos reflexivos. In ALCEU, 13 (26): 86-103.

Tetrault, J. (1982). Agenda for a small planet (Phase II). The message from the South. New York: United Nations.

Valério, M. (2012). O continente pobre e católico: o discurso da teologia da libertação e a reinvenção religiosa da América Latina (1968-1992). Campinas: Tese de Doutorado, Universidade Estadual de Campinas. 


\section{Filmografia}

Viramundo (1964/1965), de Geraldo Sarno.

Viva Cariri! (1969/1970), de Geraldo Sarno.

Espaço sagrado (1975), de Geraldo Sarno.

Iâ̂. A iniciação num terreiro Gege Nagô (1976), de Geraldo Sarno.

A terra queima (1984), de Geraldo Sarno.

Deus é um fogo (1987), de Geraldo Sarno. 